\title{
Mucilage Extracted from Dragon Fruit Peel (Hylocereus undatus) as Flocculant for Treatment of Dye Wastewater by Coagulation and Flocculation Process
}

\author{
Oanh Thi Hoang Le ${ }^{D}$, Le Nhat Tran, Van Thi Doan, Quang Van Pham, Anh Van Ngo, \\ and Huan Huu Nguyen
}

Faculty of Environmental Sciences, University of Science, Vietnam National University, Hanoi, Vietnam

Correspondence should be addressed to Oanh Thi Hoang Le; hoangoanh.le@hus.edu.vn

Received 31 January 2020; Accepted 10 April 2020; Published 11 May 2020

Guest Editor: Pei-Yu Kuo

Copyright (c) 2020 Oanh Thi Hoang Le et al. This is an open access article distributed under the Creative Commons Attribution License, which permits unrestricted use, distribution, and reproduction in any medium, provided the original work is properly cited.

\begin{abstract}
Dye wastewater from textile industries shows very low biodegradability due to high molecular weight and complex structures of dyes. So far, the most simple method for treatment of this type of wastewater has been coagulation and flocculation. This study determined the removal of turbidity and other pollutants from dye wastewater by mucilage extracted from the peel of dragon fruit (Hylocereus undatus) and its effect in reducing synthetic chemical polyaluminum chloride (PACl) used in coagulation and flocculation (CF) process. The removal of turbidity in a sequent $\mathrm{CF}$ process using $\mathrm{PACl}$ and dragon fruit mucilage was investigated based on Jar tests. Maximum coagulation efficiencies of $\mathrm{PACl}$ were typically observed at $\mathrm{pH} 4.0-6.0$ and $\mathrm{PACl}$ concentrations of about $100-150 \mathrm{mg} / \mathrm{L}$ depending on types of wastewater, whereas optimal settling times were 30-60 minutes, respectively. The addition of dragon fruit mucilage $(0.5-50 \mathrm{mg} / \mathrm{L})$ after PACl $(75-245 \mathrm{mg} / \mathrm{L})$ resulted in turbidity removal efficiencies up to $95 \%$. The addition of mucilage extracted from dragon fruit peels was proven to increase turbidity removal efficiency and decrease PACl use. The increase of turbidity removal was often estimated at 10-32\%, whereas PACl used was about $3-10 \%$ less compared to total $\mathrm{PACl}$ needed for obtaining comparable efficiency when used alone. The flocculation activity of mucilage was also compared to polyacrylamide (PAM) - a synthetically organic flocculant. Since the peel of a dragon fruit is an abundant agriculture waste in Vietnam, using its extracted mucilage as a flocculant is an environmentally friendly method.
\end{abstract}

\section{Introduction}

In water treatment techniques, coagulation-flocculation is an important process to remove turbidity in water as well as contributes to increasing the efficiency of subsequent treatment processes such as sedimentation, filtration, and disinfection. Synthetic coagulants and flocculants such as aluminum salts, iron salts, and polymers ( $\mathrm{PACl}$, polyacrylamide, polyacrylic acid) are still widely used in water treatment [1]. However, some researches have shown health and ecosystem concerns when using these chemicals. For examples, Alzheimer's disease is confirmed to be related to aluminum residues in domestic water [2]. Monomers of polymer flocculants cause neurotoxicity and cancer [3]. Moreover, these chemicals are imported in developing country with a considered cost. Today more and more interests are drawn on natural coagulants and flocculants since they could minimize chemical residues, make use of various and diverse sources of waste, and reduce the risk of disease and are easily biodegradable [4].

Mucilages are polysaccharides, widespread in a number of plants, swell when dissolved in water, and form a viscous form similar to gelatin [5]. They have been used in the removal of pollutants from wastewater in both coagulant [6-8] and flocculant [9-11] roles with removal efficiency of suspended solids (SS) fluctuated from very low (about $26 \%$ ) to quite high (about 89-97\%). Mucilages extracted from fenugreek and okra have been shown to be as effective 
as synthetic coagulant (polyacrylamide) in treatment of textile and tanning wastewaters. The SS removal was $95 \%$ with mucilage concentration of $0.04 \mathrm{mg} / \mathrm{L}$ (fenugreek) and $0.12 \mathrm{mg} / \mathrm{L}$ (orka) [4]. Experiments conducted on synthetic wastewater (kaolin and humic acid suspension, 63-73 NTU) resulted in turbidity removal of $96.3-97.4 \%$ and 93.0-97.3\% when using mallow and okra mucilages as flocculants, respectively [9].

The textile industry is an industry with multistage technology lines, using a lot of materials as well as chemicals, and is one of the most polluted industries [12]. It uses a large amount of water to serve the production stages, and at the same time, discharges average $200-350 \mathrm{~m}^{3}$ wastewater per ton of fabric products. In which, the disperse dyeing process generates about $91-129 \mathrm{~m}^{3} /$ ton product [13]. According to the World Bank, about $17-20 \%$ of industrial wastewater comes from textile dyeing and finishing [14]. Wastewater from textile establishments is largely fluctuated both in the flow and the load of pollutants, depending on season, production capacity, and product quality. Basically, the use of many types of dyes, chemicals, and additives leads to wastewater often with high color, organic matters, etc., contributing to environmental pollution and diseases in humans [13]. About $40 \%$ of the colorants used globally contain organic chlorine, a carcinogen [15]. Chemicals used in dyeing could evaporate into the air hindering respiration or causing skin diseases. Characteristics of textile dyeing wastewater are varied by $\mathrm{pH}$ (1.9-14), COD (50-17900 mg/L), TSS $(15-23900 \mathrm{mg} / \mathrm{L})$, and strongly colored $(50-2500 \mathrm{Pt} / \mathrm{Co})$ as summarized by Freitas et al. [12] and Verma et al. [13]. Different mucilages (Opuntia ficusindica, Cereus peruvianus, and Ocimum basilicum) were found effective as flocculants in coagulation-flocculation treatment of industrial textile wastewater $[8,10,11,16]$.

Most Hylocereus species, being in the same family as cactus, originate principally from Latin America (probably from Mexico and Colombia), with others possibly from the West Indies, and have been a food source for inhabitants [17]. Today, they are distributed all over the world (in tropical and subtropical regions), and Hylocereus undatus (white flesh dragon fruit) is the most cosmopolitan species. In Vietnam, $H$. undatus has been widely grown for fruit harvesting in the provinces and cities across the country, with largest areas in the South [18]. Mucilage is present in some parts of the dragon fruit plant such as the stem, leaf, and fruit. The cactus mucilage contains galacturonic acid which is generally the predominant active coagulation agent regardless of the species [19]. High natural polymers such as polysaccharides (e.g., galacturonic acid) and proteins in dragon fruit provide active sites at the polymeric chain for particle adsorption and encourage the coagulation process [19-21]. So far, there has been only one investigation by Ismail et al. [17] on coagulation activity of the dragon fruit peel (considered an agricultural waste) for removal of turbidity from landfill leachate.

This study considered the turbidity removal efficiency of mucilage extracted from the dragon fruit peel as the role of a flocculant ( $\mathrm{PACl}$ as coagulant) in removal of turbidity from dye wastewater.

\section{Materials and Methods}

2.1. Materials. The Hylocereus undatus peels were collected from a fruit juice shop for use as a material to extract mucilage. Three samples of textile wastewater were taken from Huy Phat dyeing company (Duong Noi, Ha Dong, Hanoi, Vietnam), which were characterized according to APHA [22] as in Table 1. PACl (AC100S) and PAM (A1110) were purchased from Grasim Industries Ltd. (India) and KMR (UK), respectively.

\subsection{Methods}

2.2.1. Extraction of Mucilage from Dragon Fruit Peel. The peels were washed to remove dirt and chopped to $5 \mathrm{~mm}$, taken to dry at a temperature of $50^{\circ} \mathrm{C}$ until constant weight. The extraction process was executed in two steps.

Step 1: mucilage separation. Dried peels were mixed with distilled water (ratio $1: 8 \mathrm{w} / \mathrm{v}$ ) and heated at $60^{\circ} \mathrm{C}$ in water bath for 1 hour (the mixture was stirred regularly). After that, the mixture was taken out and cooled to room temperature within 1 hour to increase the amount of mucilage dissolved in distilled water. Thereafter, the mixture was filtered through 8 layers of muslin cloth to collect the filtrate containing the mucilage.

Step 2: mucilage precipitation and collection. The mucilage was precipitated from the filtrate by acetone with the volume ratio of $3: 1$. The precipitate was washed 3-4 times with concentrated alcohol to remove adhesives on its surface and dried at a temperature of $40^{\circ} \mathrm{C}$ until the constant weight. After being dried, the mucilage was grounded, put into a zip bag, and placed in a desiccator for storage.

\subsubsection{Characterization of Mucilage Extracted from Dragon} Fruit Peel. Fourier transform infrared spectra (FTIR) were obtained using the Nicolet Is50 Spectrometer in the resolution range of $4000-400 \mathrm{~cm}^{-1}$, data interval of $0.47 \mathrm{~cm}^{-1}$ with 16 scans.

Zeta potentials were measured on mucilage suspensions of $20 \mathrm{mg} / \mathrm{L}$ at different $\mathrm{pHs}$ ranging from 4 to 9 using PCD05, Muetek device.

\subsubsection{Turbidity Removal from Dye Wastewater by Mucilage as Flocculant}

(1) Optimal Working Conditions of Coagulant PACl on Dye Wastewater. For settling time and $\mathrm{pH}$, experiments were conducted according to the Jar test model [9] under room temperature $\left(27 \pm 2^{\circ} \mathrm{C}\right)$. Initial $\mathrm{pH}$ was varied between 4 and 9 (adjusted with $\mathrm{NaOH}$ and $\mathrm{HCl}$ ). $\mathrm{PACl}$ was added to wastewater at fixed concentrations, stirred quickly at $200 \mathrm{rpm}$ within 1 minute, stirred slowly at 30-40 rpm for 10 minutes, and allowed to settle for 10, 20, 30, 40, 50, and 60 minutes. The turbidity removal was assessed by measuring of the turbidity of water after treatment at a water depth of $3 \mathrm{~cm}$ under the surface, using a Hach $2100 \mathrm{Q}$ turbidity meter.

For the PACl dosage, experiments were carried out similarly at optimal $\mathrm{pH}$ and settling time and $\mathrm{PACl}$ concentrations in the range of $50-900 \mathrm{mg} / \mathrm{L}$, respectively. 
TABLE 1: Characteristics of dye wastewater samples.

\begin{tabular}{|c|c|c|c|c|c|c|}
\hline $\begin{array}{l}\text { Wastewater } \\
\text { sample }\end{array}$ & Dyes & $\mathrm{pH}$ & Turbidity (NTU) & TSS (mg/L) & Color index $(\mathrm{Pt} / \mathrm{Co})$ & $\mathrm{COD}(\mathrm{mg} / \mathrm{L})$ \\
\hline $\mathrm{R}$ & $\begin{array}{l}\text { Red GS } 1.8 \% \\
\text { Red FB } 0.4 \%\end{array}$ & 7.04 & 319 & 800 & 1327 & 960 \\
\hline VB & Violet S3R 1.2\% Blue 2BLN 0.6\% red SB 0.4\% & 6.72 & 403 & 670 & 1027 & 1536 \\
\hline NB & $\begin{array}{c}\text { Navy HGL } 2.6 \% \text { Black EXSF } 0.7 \% \\
\text { Red GS 0.3\% }\end{array}$ & 7.10 & 469 & 511 & 1366 & 2496 \\
\hline
\end{tabular}

(2) Turbidity Removal in Sequent Coagulation and Flocculation Process Using $\mathrm{PACl}$ and Mucilage. Similar experiments were employed, but mucilage was introduced in a slow mixing stage after the use of $\mathrm{PACl}$ in a flash mixing stage to increase the size and sedimentation capacity of colloidal particles, while reducing the amount of $\mathrm{PACl}$ used. The experiments were carried out at the optimal $\mathrm{pH}$ and settling time and $\mathrm{PACl}$ with lower concentrations than the optimal concentrations. Mucilage concentrations were varied between 0 and $50 \mathrm{mg} / \mathrm{L}$ for all dye wastewater samples.

\section{Results and Discussion}

3.1. Characteristics of Mucilage Extracted from the Dragon Fruit Peel. FTIR spectrum (Figure 1(a)) shows three major bands associated with the carbohydrate moieties (region $\sim 1150-900 \mathrm{~cm}^{-1}$ ), protein (region 1654-1635 $\mathrm{cm}^{-1}$ ), and hydroxyl (region $\sim 3410 \mathrm{~cm}^{-1}$ ) bands, which were distinctly visible in case of mucilage extracted from the dragon fruit peel. Carboxyl and phenolic groups are recognized at 1100.60$1018.74 \mathrm{~cm}^{-1}$ with C-OH stretching [23]. The absorption bands at $1635.2 \mathrm{~cm}^{-1}$, associating with ester carbonyl and carboxyl groups, suggested the possible presence of uronic acid in polysaccharides [24]. The band at $1749 \mathrm{~cm}^{-1}$ is evidently not present, indicating a low degree of esterification of mucilage [25]. This is beneficial in enhancing properties of water absorption, viscosity, and texture formation of mucilage. Another band was found at $2929.43 \mathrm{~cm}^{-1}$ due to C-H stretching and bending vibration, which corresponds to the vibrations of $-\mathrm{CH}$ and $-\mathrm{CH}_{2}$ present in the mucilage molecule [26]. Additionally, a band at $3411.91 \mathrm{~cm}^{-1}$ was found, which corresponds to $\mathrm{O}-\mathrm{H}$ stretching of alcohol and carboxylic acid. -OH groups involved in intermolecular hydrogen bonding of mucilage molecules, as mentioned by Habibi et al. [27].

Zeta potentials of mucilage suspensions at $20 \mathrm{mg} / \mathrm{L}$ concentration show a negative charge nature (Figure 1(b)). Moreover, this value is rather stable in a $\mathrm{pH}$ range from 6 to 9 , implying stable working ability at different pHs. At acidic $\mathrm{pH}$ of 4 and 5, negative-charged groups on the polysaccharide are protonated and therefore less negative. The ability to work stably at different $\mathrm{pHs}$ is the advantage of natural flocculants in comparison to chemical ones $[6,19]$.

\subsection{Efficiency of Mucilage as a Flocculant in Treatment of Dye Wastewater}

\subsubsection{Appropriate Coagulation Conditions of PACl}

(1) Optimal Settling Time and $p H$. The experiment was performed on all three types of dye wastewater using suitable $\mathrm{PACl}$ dosages for observation of the effect of settling times and $\mathrm{pHs}$ on turbidity removal efficiency (Figure 2).

Generally, a pH range from 4 to 6 showed high and stable turbidity removal, while a $\mathrm{pH}$ range from 7 to 9 showed much lower turbidity removal. According to the initial $\mathrm{pH}$ of wastewater (around 7), $\mathrm{pH} 6$ was found most suitable for the reason of chemical saving regarding $\mathrm{pH}$ adjustment.

Settling times increasing from 10 to 60 (10 minutes interval) increased the turbidity removal. After 30 minutes of settling time, there were large changes in both turbidity removal (up to 6\%) and sludge volume (up to 96\%). However, for settling times from 30 to 60 minutes, small changes in turbidity removal (mostly around 1\%) but no changes in sludge volume were observed. Balancing the three factors (turbidity removal, sludge volume, and hydraulic retention time), settling time of 40 minutes was selected for all three types of wastewater in further experiments.

The effect of initial $\mathrm{pH}$ on turbidity removal is correlated with speciation characteristics of $\mathrm{PACl}$. Both monomeric and polymeric aluminum species are present when $\mathrm{PACl}$ is in water [28]. Of which, $\mathrm{Al}_{13}\left[\left(\mathrm{AlO}_{4} \mathrm{Al}_{12}(\mathrm{OH})_{24}\left(\mathrm{H}_{2} \mathrm{O}\right)_{12}\right]^{7+-}\right.$ and $\mathrm{Al}_{30} \quad\left[\left(\mathrm{AlO}_{4}\right)_{2} \mathrm{Al}_{28}(\mathrm{OH})_{56}\left(\mathrm{H}_{2} \mathrm{O}\right)_{26}\right]^{18+}$ are generally believed to be the most effective coagulation species in polyaluminum coagulants $[29,30]$. At a $\mathrm{pH}$ range from 4 to 6 , polymeric aluminum species are dominant $[31,32]$. These positive species benefit flocs growing because they easily neutralize negative charges of dye wastewater causing destabilization of colloids and facilitate the physical or chemical adsorption of the destabilized colloids [30]. When working $\mathrm{pH}$ gets higher, $\mathrm{PACl}$ hydrolyzed faster [31] to form amorphous $\mathrm{Al}(\mathrm{OH})_{3}$ and later $\mathrm{Al}(\mathrm{OH})_{4}^{-}$. The increase of $\mathrm{pH}$ also results in the decrease of charge neutralization capacity of $\mathrm{PACl}$ [31]. Furthermore, $\mathrm{pH}$ also affects the physical and chemical properties of colloids in dye wastewater. The lower $\mathrm{pH}$ improves protonation to make colloids easier to be charge-neutralized and charge-destabilized [30]. Besides, $\mathrm{pH}$ could affect the balance between the reaction of organic functional groups with hydrogen ions and aluminum hydrolyzates [33].

Textile wastewater has $\mathrm{pH}$ varied from acidic to basic, however typically neutral [13]. Effective coagulation condition at $\mathrm{pH}$ around a neutral $\mathrm{pH}$ is advantageous because no or less chemicals are needed to adjust the $\mathrm{pH}$ of wastewater. 


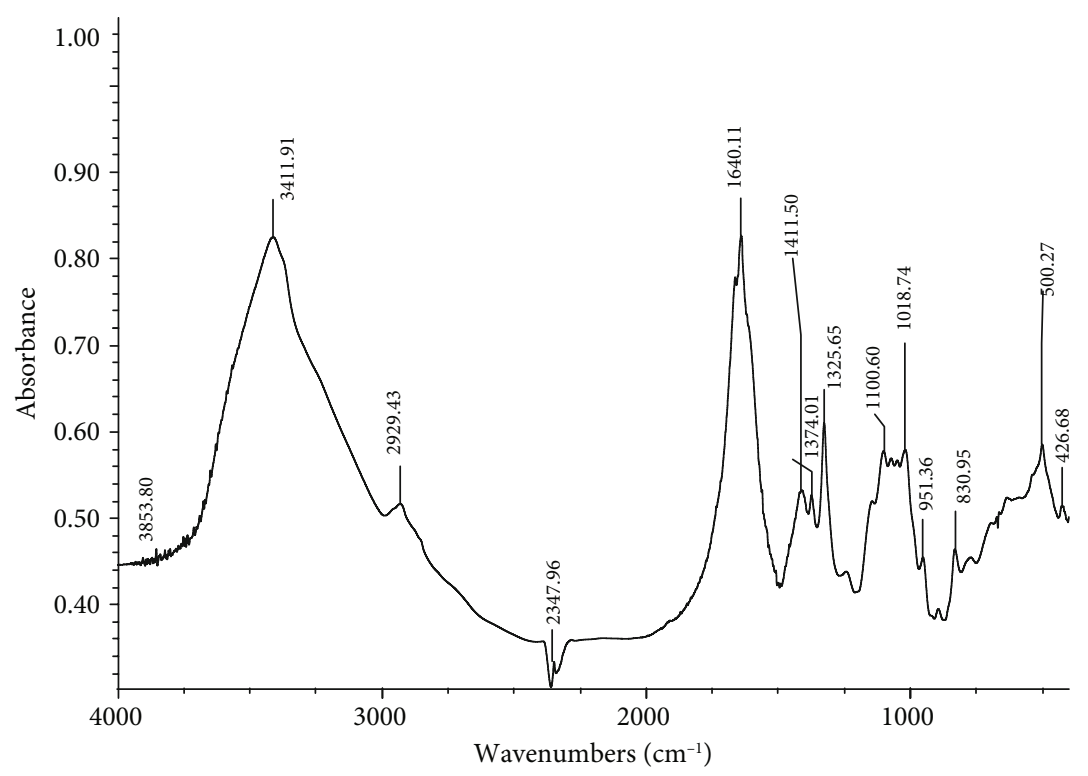

(a)

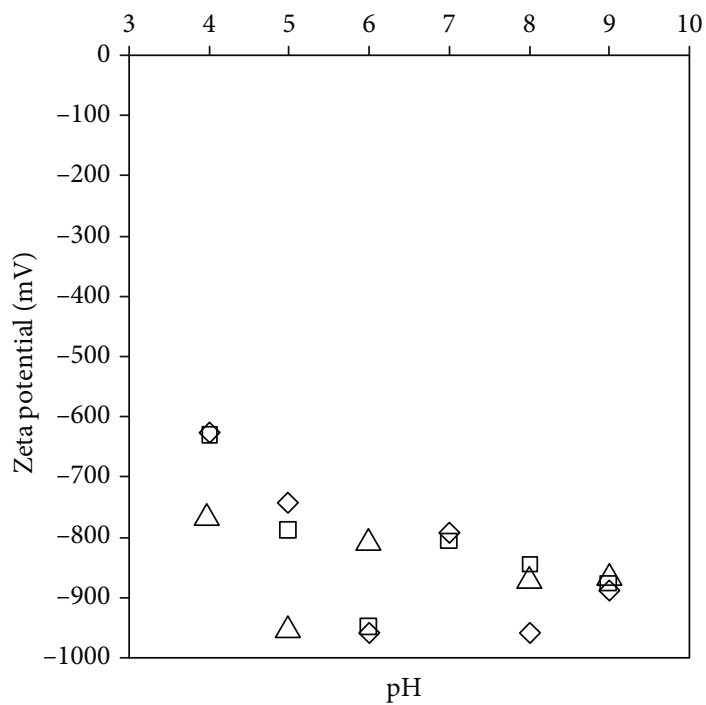

(b)

FIGURE 1: FTIR spectrum (a) and zeta potential (b) of mucilage extracted from the dragon fruit peel.

The settling capability of flocs produced after the coagulation process is greatly dependent on the type of coagulant, the type of wastewater, and also, the floc size generated during treatment [1]. Flocculants are capable of producing a larger floc size, mainly formed by adsorption and bridging involving long chain polymers during flocculation for rapid settling [1]. The results of this study are similar to the study of Lee et al. [34] when it was found that the effective removal of turbidity took place within 30 minutes. Longer than 30 minutes, the increase was not significant (1-2\%). The settling time of 30-60 minutes is in line with researches listed in Lee et al. [4] on flocculation efficiencies of plantbased flocculants.

(2) Appropriate Dosage of PACl. The effect of PACl dosages on turbidity removal under optimal $\mathrm{pH}$ and settling time is shown in Figure 3. When PACl was increased until optimal dosage, the turbidity removal was increased up to $97 \%$. The optimal PACl dosages were dependent on the types of dye wastewater and ranged between 100 and $150 \mathrm{mg} / \mathrm{L}$. The high turbidity removal was kept stable until it was going down at certain higher PACl dosages. To research mucilage as a flocculant when combined with $\mathrm{PACl}$, the dosage of $\mathrm{PACl}$ was chosen at a value lower than the optimal dosage.

Optimal coagulant dosage is established as a significant and critical factor to control the performance, the cost, and the sludge formation [1]. It is believed that the major coagulation mechanism of $\mathrm{PACl}$ is charge neutralization, bridging, and sweeping $[29,35]$. The higher the dosage of $\mathrm{PACl}$, the higher its neutralization capacity is. Because more positive aluminum hydrolyzates are present in solution as counter 
$\mathrm{R}$
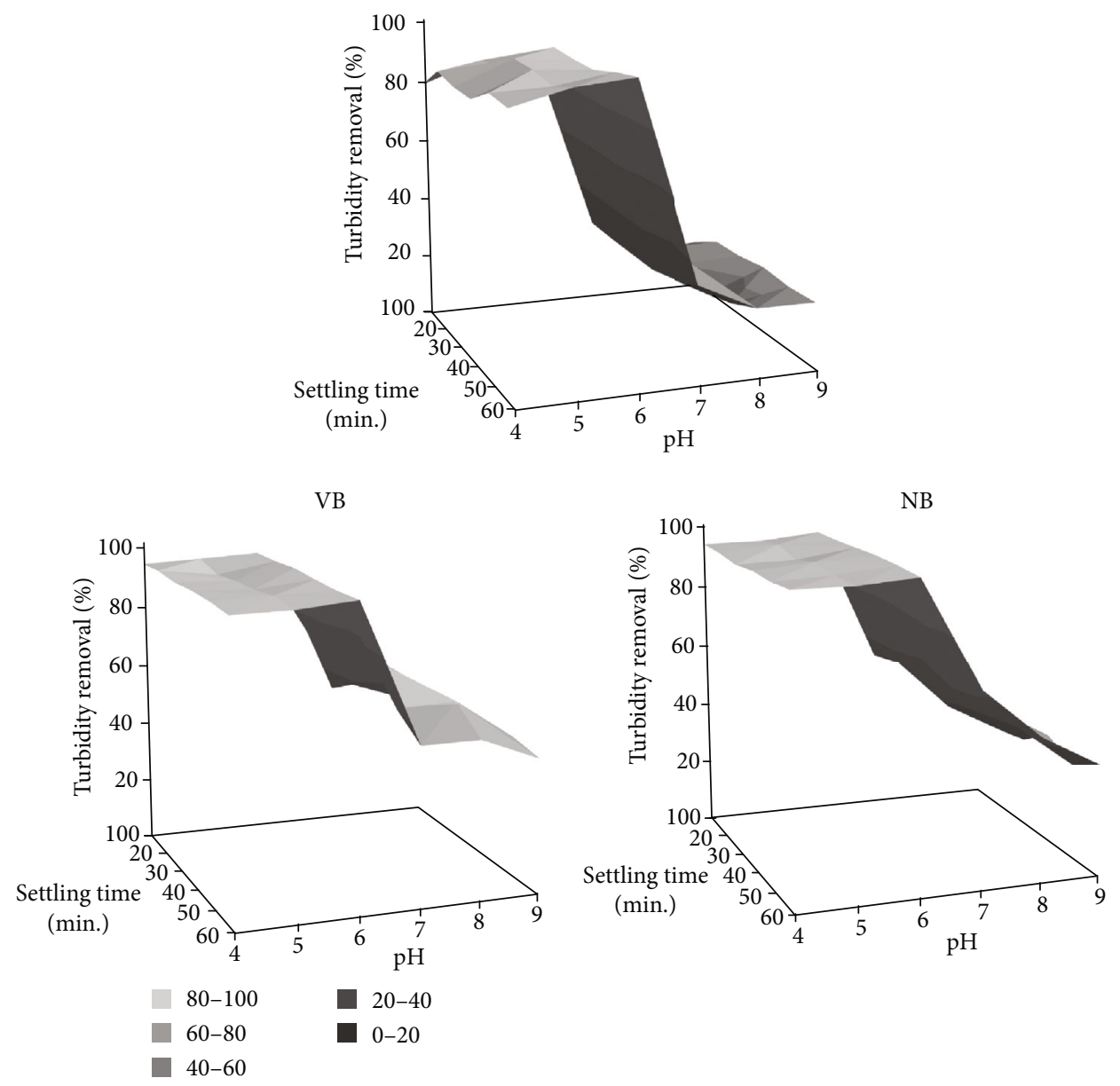

FIGURE 2: The effect of $\mathrm{pH}$ and settling time on turbidity removal by $\mathrm{PACl}$.

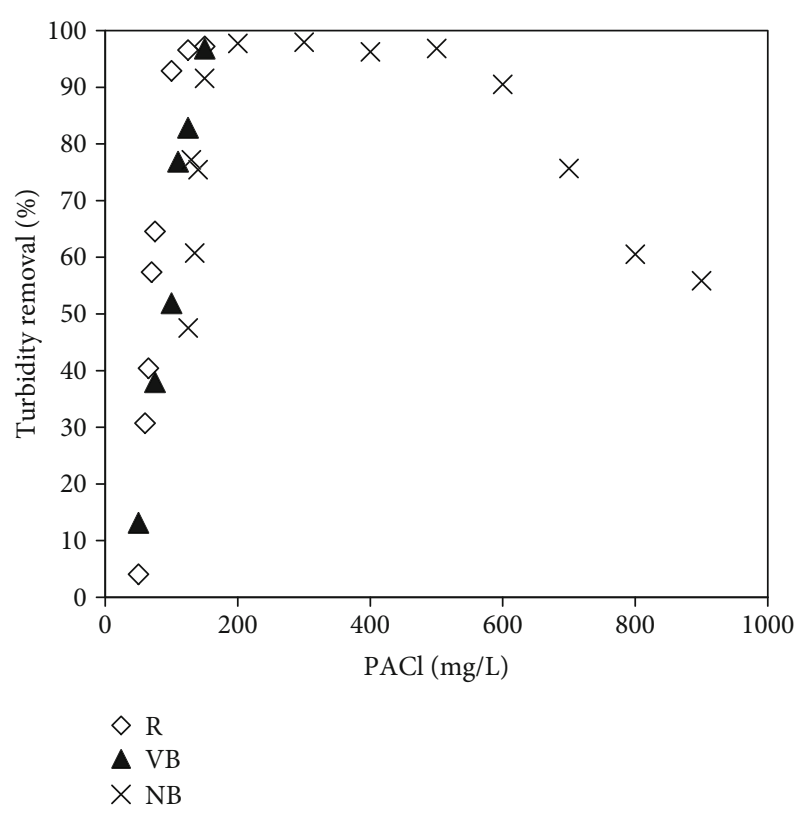

Figure 3: The effect of PACl dosages on turbidity removal. ions of negative colloids present in dye wastewater. Similarly, the higher the $\mathrm{PACl}$ dosage, the more polymeric aluminum species appear in the solution, which in turn assist the bridging mechanism. Charge neutralization, leading to particle destabilization, is dominant with a smaller dosage of $\mathrm{PACl}$, while sweep floc coagulation is dominant with a higher dosage of $\mathrm{PACl}$ [35]. In a suitable range, the higher the coagulant dosage, the higher the turbidity removal efficiency could be [36]. Excess dosages of coagulants cause resuspension of aggregated particles that results in reduction of coagulation efficiency [1]. In accordance with turbidity removal, COD removal also exhibits a similar trend [37].

3.2.2. Treatment Efficiency of Mucilage as in Combination with Coagulant PACl for Dye Wastewater. The turbidity removals of mucilage in the role of flocculant for $\mathrm{PACl}$ are shown in Figure 4 . The addition of mucilages $(5-50 \mathrm{mg} / \mathrm{L}$ ) increased turbidity removal up to the highest value of about 95\%. These increases often ranged between 10 and 32\%. To obtain comparable turbidity removal for all three types of dye wastewater, around $10 \mathrm{mg} / \mathrm{L} \mathrm{PACl}$ more was needed, accounting for $3-10 \%$ of total PACl used (100, 150, and $150 \mathrm{mg} / \mathrm{L}$ for wastewater $\mathrm{R}, \mathrm{VB}$, and $\mathrm{NB}$, respectively). The mucilage concentrations which were most efficient in 

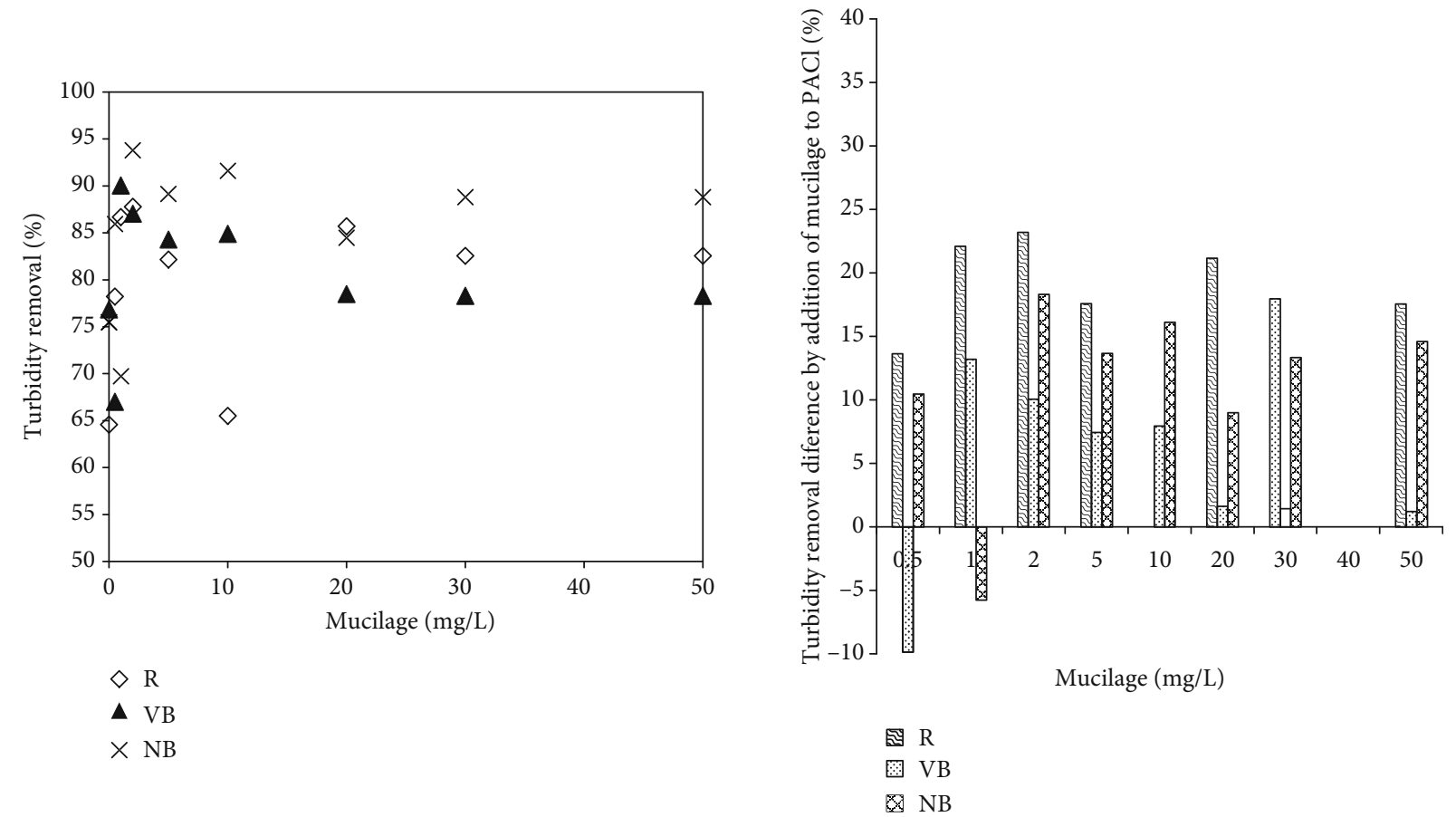

FIGURE 4: Turbidity removal efficiency of mucilage in combination with PACl.
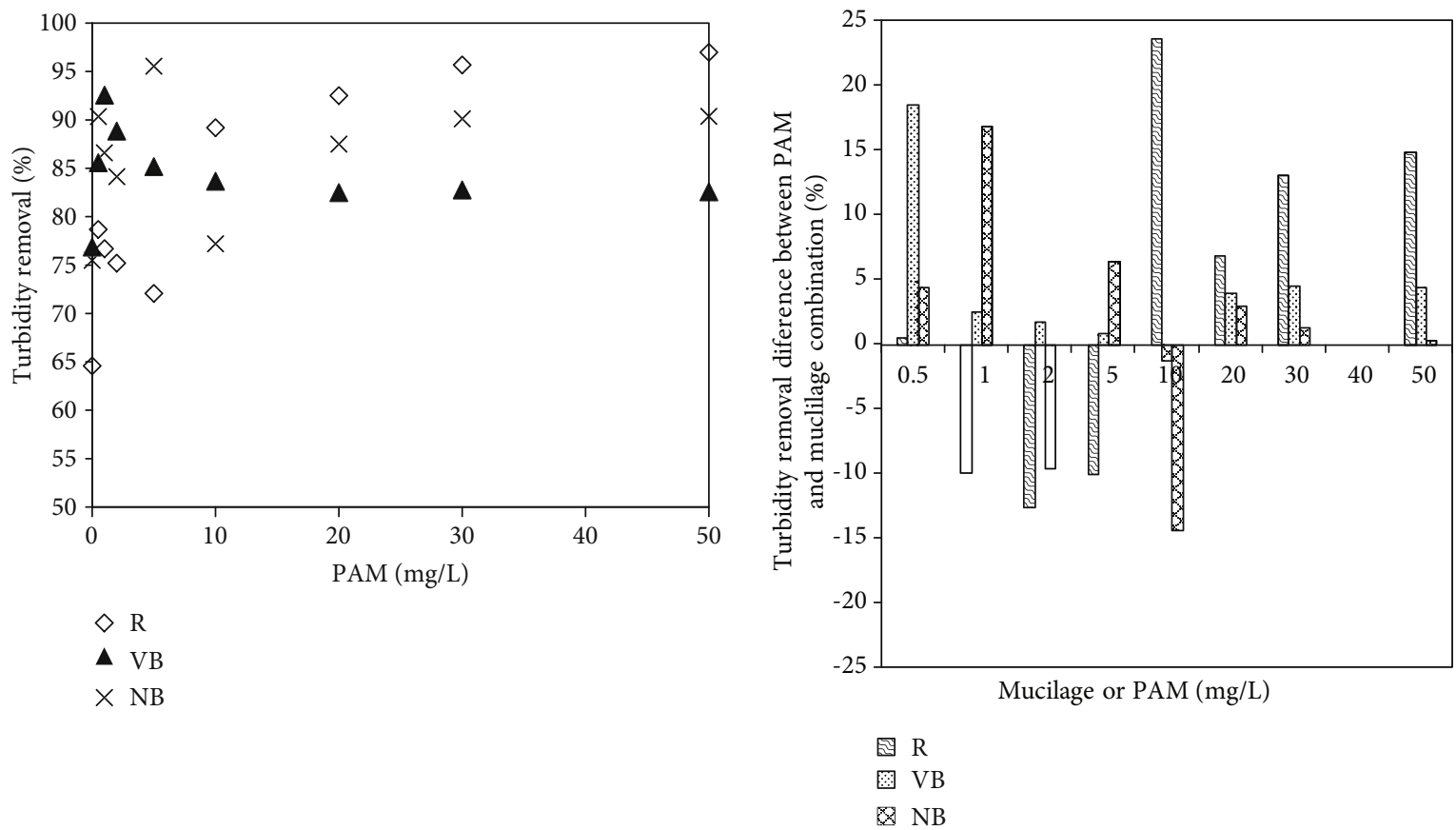

FIgURE 5: Turbidity removal of PAM in combination with PACl and its comparison with those of mucilage.

increasing the turbidity removal lied under $20 \mathrm{mg} / \mathrm{L}$. Higher mucilage concentrations resulted in lower turbidity removal.

The flocculation activity of mucilage was compared to polyacrylamide (PAM) in Figures 5 and 6. PAM had more stable performance than mucilage and often showed continuous increase of turbidity removal when its dosage increased in investigated range $(0.5-50 \mathrm{mg} / \mathrm{L})$. The flocs formed by
PAM were much larger than those formed by mucilage. More often, its ability in flocculation was better than mucilage and the differences in removal efficiency could be more than $20 \%$, but in many cases less than 5\%. Sometimes, mucilage showed better activity as the differences went minus.

Overall, treatment efficiency of mucilage as a flocculant for PACl was high for turbidity (88-95\%), color (87-93\%), and TSS (53-97\%) and lower for COD (20-50\%) (Figure 6). 


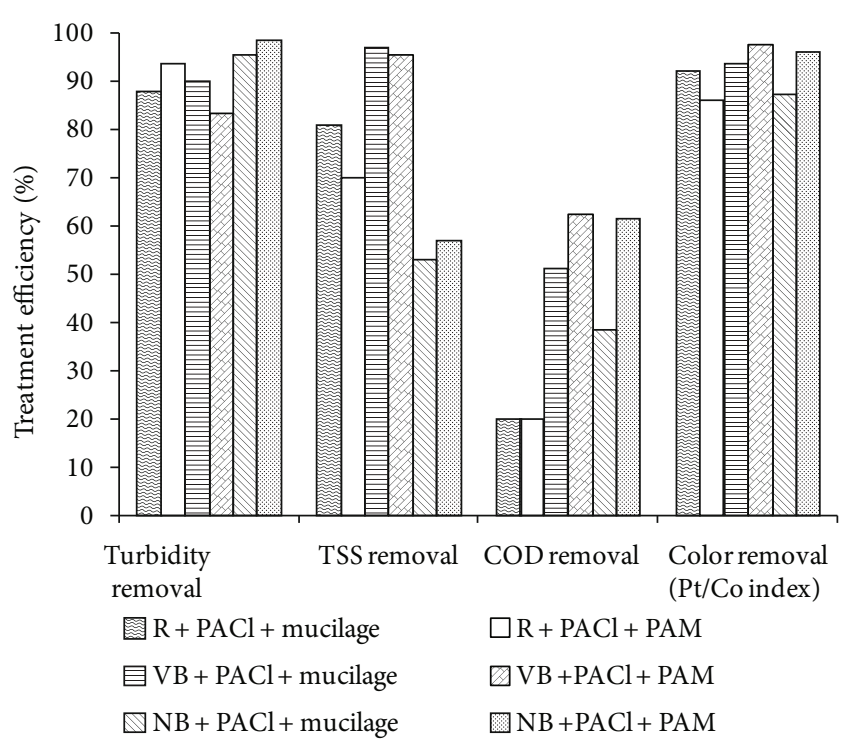

Figure 6: Pollutant removal of mucilage and PAM in combination with PACl.

Compared to those of PAM, these treatment efficiencies could be higher but more likely lower, especially in terms of turbidity and COD.

The hydrocolloid characteristics of mucilage are the basis for its utilization as bioflocculant. The mucilage from the dragon fruit peel is a heteropolysaccharide with rheological properties that are of great application [20]. A component of mucilage-galacturonic acid plays an important role in turbidity reduction, in combination with galacturonic acid, arabinose, galactose, and rhamnose also contribute to turbidity removal [21]. The turbidity removal efficiencies brought by the mucilage from the dragon fruit peel were similar to or higher than those achieved by mucilages from different cactuses on dye wastewaters in de Souza et al. $[10,11]$ and Bouatay and Mhenni [16], while its COD removals were lower. Likewise, the increase of $\mathrm{PACl}$ coagulation efficiency for turbidity by mucilage was comparable or even higher than that of PAM in combination with alum and PACl in treatment of pulp and paper mill wastewater [38]. Lower COD removal than turbidity, color, and TSS removals was also found in common $[10,11,16,39]$.

The mucilage concentrations which are higher than optimum concentration lead to the decrease of turbidity removal because of the restabilization of the solution. The optimum amount of flocculant causes the maximum amount of particles to aggregate and settle. Beyond the optimum dose, steric stabilization of the particle took place and increase the turbidity $[7,9]$.

\section{Conclusions}

The mucilage obtained from the dragon fruit peel has shown a flocculation effect and the potential to save PACl and limit its harmful effects in the coagulation and flocculation process to remove turbidity and other pollutants from three different types of dye wastewater. The efficient operating dosages of mucilage ranged in $0.5-20 \mathrm{mg} / \mathrm{L}$, attaining turbidity removal efficiency at maximum of $95 \%$ with $10-32 \%$ increase compared to $\mathrm{PACl}$ coagulation alone, and the $\mathrm{PACl}$ saving could be about $3-10 \%$ for achieving comparable efficiency. Comparing to PAM, its efficiency was not as stable but sometimes even better or just similar with differences of less than $5 \%$. Therefore, the mucilage from the dragon fruit peel is a potential green alternative in treatment of dye wastewater.

\section{Data Availability}

The datasets generated during and/or analysed during the current study are available from the corresponding author on reasonable request.

\section{Conflicts of Interest}

The authors declare that they have no conflicts of interest.

\section{Authors' Contributions}

All authors commented on previous versions of the manuscript and read and approved the final manuscript. All authors contributed to the study conception and design with detailed contribution as the following: Oanh Thi Hoang Le is the first and corresponding author, who is responsible for conceptualization, experiment design, data synthesis, analysis, and interpretation, as well as writing and finalizing the article. Le Nhat Tran is a coauthor, who carried out experiments, especially jar tests, and partly contributed to the first draft of the article. Van Thi Doan is a coauthor, who carried out experiments and analyzed characterizing parameters of dye wastewater and the mucilage. Quang Van Pham is a coauthor, who carried out the sampling trips for obtaining dye wastewater and supervised analytical processes, as well as provided FTIR measurement and interpretation of the corresponding results. Anh Van Ngo is a coauthor, who contributed to experiment design and revised the content of the article. Huan Huu Nguyen is a coauthor, who carried out the sampling trips for obtaining dye wastewater and supervised analysis process.

\section{Acknowledgments}

This research is funded by the Vietnam National University, Hanoi, (VNU) under project number QG.18.12.

\section{References}

[1] C. Y. Teh, P. M. Budiman, K. P. Y. Shak, and T. Y. Wu, "Recent advancement of coagulation-flocculation and its application in wastewater treatment," Industrial and Engineering Chemistry Research, vol. 55, no. 16, pp. 4363-4389, 2016.

[2] S. Polizzi, E. Pira, M. Ferrara et al., "Neurotoxic effects of aluminium among foundry workers and Alzheimer's disease," Neurotoxicology, vol. 23, no. 6, pp. 761-774, 2002.

[3] C. Rudén, "Acrylamide and cancer risk-expert risk assessments and the public debate," Food and Chemical Toxicology, vol. 42, no. 3, pp. 335-349, 2004. 
[4] C. S. Lee, J. Robinson, and M. F. Chong, "A review on application of flocculants in wastewater treatment," Process Safety and Environmental Protection, vol. 92, no. 6, pp. 489-508, 2014.

[5] G. Vijayaraghavan, T. Sivakumar, and K. A. Vimalkumar, "Application of plant based coagulation for wastewater treatment," International journal of Advanced Engineering Research and Studies, vol. 1, pp. 88-92, 2011.

[6] A. Mishra, R. Srinivasan, and R. Dubey, "Flocculation of textile wastewater by Plantago psyllium mucilage," Macromolecular Materials and Engineering, vol. 287, no. 9, pp. 592-596, 2002.

[7] A. Mishra and M. Bajpai, "Flocculation behaviour of model textile wastewater treated with a food grade polysaccharide," Journal of Hazardous Materials, vol. 118, no. 1-3, pp. 213217, 2005.

[8] S. Shamsnejati, N. Chaibakhsh, A. R. Pendashteh, and S. Hayeripour, "Mucilaginous seed of Ocimum basilicum as a natural coagulant for textile wastewater treatment," Industrial Crops and Products, vol. 69, pp. 40-47, 2015.

[9] K. Anastasakis, D. Kalderis, and E. Diamadopoulos, "Flocculation behavior of mallow and okra mucilage in treating wastewater," Desalination, vol. 249, no. 2, pp. 786-791, 2009.

[10] M. T. F. de Souza, E. Ambrosio, C. A. de Almeida et al., "The use of a natural coagulant (Opuntia ficusindica) in the removal for organic materials of textile effluents," Environmental Monitoring and Assessment, vol. 186, no. 8, pp. 5261-5271, 2014.

[11] M. T. F. de Souza, C. A. de Almeida, E. Ambrosio et al., "Extraction and use of Cereus peruvianus cactus mucilage in the treatment of textile effluents," Journal of the Taiwan Institute of Chemical Engineers, vol. 67, pp. 174-183, 2016.

[12] T. K. F. S. Freitas, C. A. Almeida, D. D. Manholer, H. C. L. Geraldino, M. T. F. de Souza, and J. C. Garcia, "Review of utilization plant-based coagulants as alternatives to textile wastewater treatment," in Detox fashion: wastewater treatment, pp. 27-79, Springer, Singapore, 2018.

[13] A. K. Verma, R. R. Dash, and P. Bhunia, "A review on chemical coagulation/flocculation technologies for removal of colour from textile wastewaters," Journal of Environmental Management, vol. 93, no. 1, pp. 154-168, 2012.

[14] V. Jegatheesan, B. K. Pramanik, J. Chen, D. Navaratna, C. Y. Chang, and L. Shu, "Treatment of textile wastewater with membrane bioreactor: a critical review," Bioresource Technology, vol. 204, pp. 202-212, 2016.

[15] N. M. Sivaram, P. M. Gopal, and D. Barik, "Toxic waste from textile industries," in Energy from Toxic Organic Waste for Heat and Power Generation, pp. 43-54, Woodhead publishing, 2019.

[16] F. Bouatay and F. Mhenni, "Use of the cactus cladodes mucilage (Opuntia Ficus Indica) as an eco-friendly flocculants: process development and optimization using statistical analysis," International Journal of Environment Research, vol. 8, no. 4, pp. 1295-1308, 2014.

[17] S. N. S. Ismail, N. A. K. Mahiddin, and S. M. Praveena, "The used of dragon fruit peels as eco-friendly wastewater coagulants," Asian Journal of Agriculture and Biology, vol. 6, Special issue, pp. 112-117, 2018.

[18] Vietnamtradeoffice, "Current status of cultivation and consumption of dragon fruits in Vietnam," 2017, https://vietnam tradeoffice.net/tinh-hinh-san-xuat-va-tieu-thu-thanh-longviet-nam/.

[19] S. Y. Choy, K. M. N. Prasad, T. Y. Wu, M. E. Raghunandan, and R. N. Ramanan, "Utilization of plant-based natural coag- ulants as future alternatives towards sustainable water clarification," Journal of Environmental Sciences, vol. 26, no. 11, pp. 2178-2189, 2014.

[20] E. E. García-Cruz, J. Rodríguez-Ramírez, L. L. Méndez Lagunas, and L. Medina-Torres, "Rheological and physical properties of spray-dried mucilage obtained from Hylocereus undatus cladodes," Carbohydrate Polymers, vol. 91, no. 1, pp. 394-402, 2013.

[21] S. M. Miller, E. J. Fugate, V. O. Craver, J. A. Smith, and J. B. Zimmerman, "Toward understanding the efficacy and mechanism of Opuntia spp. as a natural coagulant for potential application in water treatment," Environmental Science \& Technology, vol. 42, no. 12, pp. 4274-4279, 2008.

[22] APHA, Standard methods for the examination of water and wastewater, American Public Health Association, Washington, 23rd edition, 2005.

[23] S. Das, M. N. Alam, S. Batuta et al., "Exploring the efficacy of Basella alba mucilage towards the encapsulation of the hydrophobic antioxidants for their better performance," Process Biochemistry, vol. 61, pp. 178-188, 2017.

[24] S. Qian, X. Fang, D. Dan, E. Diao, and Z. Lu, "Ultrasonicassisted enzymatic extraction of a water soluble polysaccharide from dragon fruit peel and its antioxidant activity," RSC Advances, vol. 8, no. 73, pp. 42145-42152, 2018.

[25] A. Cárdenas, F. M. Goycoolea, and M. Rinaudo, "On the gelling behaviour of 'nopal' (Opuntia ficus indica) low methoxyl pectin," Carbohydrate Polymers, vol. 73, no. 2, pp. 212-222, 2008.

[26] S. Rodríguez-González, H. E. Martínez-Flores, C. K. ChávezMoreno et al., "Extraction and characterization of mucilage from wild species of Opuntia," Journal of Food Process Engineering, vol. 37, no. 3, pp. 285-292, 2014.

[27] Y. Habibi, A. Heyraud, M. Mahrouz, and M. R. Vignon, "Structural features of pectic polysaccharides from the skin of Opuntia ficus-indica prickly pear fruits," Carbohydrate Research, vol. 339, no. 6, pp. 1119-1127, 2004.

[28] A. Zouboulis, G. Traskas, and P. Samaras, "Comparison of efficiency between poly-aluminium chloride and aluminium sulphate coagulants during full-scale experiments in a Drinking water treatment plant," Separation Science and Technology, vol. 43, no. 6, pp. 1507-1519, 2008.

[29] B. Y. Gao, Y. B. Chu, Q. Y. Yue, B. J. Wang, and S. G. Wang, "Characterization and coagulation of a polyaluminum chloride (PAC) coagulant with high $\mathrm{Al}_{13}$ content," Journal of Environmental Management, vol. 76, no. 2, pp. 143-147, 2005.

[30] P. Zhang, Z. Wu, G. Zhang et al., "Coagulation characteristics of polyaluminum chlorides $\mathrm{PAC}-\mathrm{Al}_{30}$ on humic acid removal from water," Separation and Purification Technology, vol. 63, no. 3, pp. 642-647, 2008.

[31] Z. Y. Chen, B. Fan, X. J. Peng, Z. G. Zhang, J. H. Fan, and Z. K. Luan, "Evaluation of $\mathrm{Al}_{30}$ polynuclear species in polyaluminum solutions as coagulant for water treatment," Chemosphere, vol. 64, no. 6, pp. 912-918, 2006.

[32] J. M. Duan and J. Gregory, "Coagulation by hydrolysing metal salts," Advances in Colloid and Interface Science, vol. 100-102, pp. 475-502, 2003.

[33] M. Yan, D. Wang, J. Qu, W. He, and C. W. K. Chow, "Relative importance of hydrolyzed $\mathrm{Al}(\mathrm{III})$ species $\left(\mathrm{Al}_{\mathrm{a}}, \mathrm{Al}_{\mathrm{b}}\right.$, and $\left.\mathrm{Al}_{\mathrm{c}}\right)$ during coagulation with polyaluminum chloride: A case study with the typical micro-polluted source waters," Journal of Colloid and Interface Science, vol. 316, no. 2, pp. 482-489, 2007. 
[34] M. R. Lee, D. Zawawi, and A. A. A. Latif, "Coagulation-flocculation in leachate treatment using combination of PAC with cationic and anionic polymers," International Journal of Engineering Research and Applications, vol. 2, no. 4, pp. 1935-1940, 2012.

[35] N. Wei, Z. Zhang, D. Liu, Y. Wu, J. Wang, and Q. Wang, "Coagulation behavior of polyaluminum chloride: effects of $\mathrm{pH}$ and coagulant dosage," Chinese Journal of Chemical Engineering, vol. 23, no. 6, pp. 1041-1046, 2015.

[36] O. P. Sahu and P. K. Chaudhari, "Review on chemical treatment of industrial waste water," Journal of Applied Sciences and Environmental Management, vol. 17, no. 2, 2013.

[37] B. Ramavandi and S. Farjadfard, "Removal of chemical oxygen demand from textile wastewater using a natural coagulant," Korean Journal of Chemical Engineering, vol. 31, no. 1, pp. 81-87, 2014.

[38] A. L. Ahmad, S. Wong, T. Teng, and A. Zuhairi, "Improvement of alum and PACl coagulation by polyacrylamides (PAMs) for the treatment of pulp and paper mill wastewater," Chemical Engineering Journal, vol. 137, no. 3, pp. 510-517, 2008.

[39] Y. A. J. al-Hamadani, M. S. Yusoff, M. Umar, M. J. K. Bashir, and M. N. Adlan, "Application of psyllium husk as coagulant and coagulant aid in semi-aerobic landfill leachate treatment," Journal of Hazardous Materials, vol. 190, no. 1-3, pp. 582-587, 2011. 